\title{
Varieties of corruption control: introduction to special issue
}

\author{
Hans Krause Hansen • Agata Stachowicz-Stanusch
}

Published online: 6 August 2013

(C) Springer Science+Business Media Dordrecht 2013

For the past three decades the question of how corruption can be controlled transnationally has been moving up on the agendas of policy makers, NGOs and businesses. Whatever the forms, contextual meanings and short-term benefits from corrupt transactions, it has become the dominant perception that corruption destroys the legitimacy of political institutions including the rule of law, discredits private business, misallocates resources and human skills, enhances social and economic inequalities, just as it is believed to serve as an impediment to long term economic growth.

This consensus has evolved alongside the proliferation of a transnational anticorruption industry [23, 49]. Similar to the politicization of other transnational public issues like environmental degradation and human rights abuse [48], the fight against corruption has come to have its own formal and informal institutions with commercial as well as non-commercial activities addressing various aspects of the problem at hand. The transnational anti-corruption industry thus rests on the activities and resources of a plethora of state and non-state actors, mobilizing people and professions, institutions and technologies, as well as money, for the conduct of corruption control. More than anything, it comprises legislative work in national and supranational fora, the creation of anti-corruption standards and guidelines to be deployed in organizations, as well as legal and forensic investigations of suspicious cases. It also involves consultancy in development aid such as advisory for organizations in search of knowledge and expertise about compliance programs, including whistle-blowing systems and other reporting mechanisms. The anti-corruption industry produces rankings and assessment tools that help to measure and compare the corruption risk of regions, industries, transactions and individuals, and it plays an important role in creating databases and surveillance technologies that can assist preventive work, including due diligence of agents in foreign markets and with respect to corporate mergers and acquisitions. And, not least, the anticorruption industry also spearheads capacity and training programs devoted to moral

H. K. Hansen $(\bowtie)$

Copenhagen Business School, Copenhagen, Denmark

e-mail: hkh.ikl@cbs.dk

\section{A. Stachowicz-Stanusch}

Silesian University of Technology, Gliwice, Poland 
education at universities and business schools, and in other public and private organizations, to mention just a few examples from this vibrant industry.

For a long time the main focus of the anti-corruption industry was on corruption in the so-called transition economies of Eastern Europe, and the global South. Particular attention was devoted to the project of improving public governance in these parts of the world. Over the years, however, the anti-corruption industry has also come to address the role of Western based global businesses as both perpetrators of corruption and keys to controlling it. The anti-corruption industry is full of paradoxes. It has become acutely aware of the fact that while central IOs like the European Union [57] and the World Bank [58] pay attention to the corruption problem these organizations have themselves been deeply involved in corruption. Nonetheless, important knowledge resources for the anti-corruption industry are provided by its main constituents among selected IOs including the World Bank and the United Nations, INGOs such as Transparency international, business associations like the International Chamber of Commerce, world and regional consultancies such as the Big Four, investigative journalists from traditional and new media, and other professionals including legal specialist and accountants [16]. But also scholars from a wide range of disciplines who have been investigating the mechanisms and contexts of corruption for quite some time have contributed with their knowledge about corruption and how it might be controlled. The predominant definition of corruption in the scholarly mainstream is the misuse of public office or other forms of entrusted power for private or organizational benefit. As concept, corruption thus depicts a wide range of exchanges with multiple meanings, but generically it usually refers to secretive transactions, exchanges or relationships. These are conceptualized as largely invisible unless institutionalized in terms of routine and accepted ways of engaging with authorities. Unsurprisingly, the concept of corruption is subject to continuous debate and controversies, not least due to the moral undertones, universalizing pretensions, mobilizing capacity and stigmatizing effects that the term itself and its various derivatives are carrying when invested in political struggles $[5,6,8,9,30]$.

The current global financial crisis has fuelled concerns about high levels of misuse of entrusted power for private and organizational benefit, including widespread evidence of Western corporate complicity in the proliferation of corruption scandals $[8,27]$. It has also drawn attention to the sophisticated mechanisms that enroll actors across boundaries in grey-zone activity and outright crime. Business transactions are increasingly transnational in nature. They involve high degrees of anonymity and pass through various institutions in different jurisdictions, all of which enhances opportunities for externalizing risk and evading prosecution in case something suspicious is being detected by someone [60]. At the organizational level the persistence of corruption suggests the presence of complex processes of rationalization and socialization, even when organizations have formally implemented corruption control systems [4].

It is indeed difficult to regulate transactions within and between businesses, and between businesses and public sector organizations [11, 13, 33, 46, 57]. Nonetheless, it would be misleading to consider the proliferation of corruption scandals as symptomatic of the smooth and unproblematic continuance of corruption as such. On the contrary, the expansion of aspirations of corruption control, as evidenced by the rise of the anti-corruption industry, has taken place in the same period as multinational 
corporations have come to play a central role in the global political economy. Scholars have identified multinational corporations as key drivers behind contemporary globalization as they account for a substantial part of global commerce and in many cases have considerable more clout than states [39]. However, there are also signs that corporations have begun to assume broader societal responsibilities in the face of weakened state capacities, at least officially [50]. Corporations are increasingly made the subject of scrutiny by public media and watchdogs, a fact that has led scholars to analyze and theorize the regulatory role of the reputational risks that emerge as a consequence of the increasing corporate visibility [42, 43]. The aspiration of corruption control is therefore likely to have regulatory implications at multiple levels and in many domains, including in the private sector. The question is how this regulation takes place in practice and what effects it may have.

\section{Corruption and its public enemies: investigating changing regulatory landscapes}

This special issue investigates recent trends of contemporary corruption control efforts, with a particular emphasis on regulatory changes and the role of private actors and soft law in anti-corruption work. It is based on cross-disciplinary conceptual as well as empirical work conducted in a variety of geographical and organizational contexts. Much research on transnational corruption control has focused on international regime building, the role of states and anti-corruption agencies, policymaking, legislation and enforcement since the 1990s. Scholars have also investigated the role of NGOs, the rationales propelling international organizations to spearhead anti-corruption efforts as well as regional dynamics of international anti-corruption $[1,3,6,9,13,20,30,34,35,53,59,61]$. The position of non-state actors including the private sector in corruption control continues to be an understudied subject [10, $18,28,41,47]$. Our focus in this special on this aspect of corruption control ties in with a growing body of research analyzing the involvement of private actors in the creation, management and enforcement of rules and standards in different issue areas, epitomized by concepts such as private authority, private governance, and business power $[12,17,21,24-26]$. The assumption is that states rely on an expanding number of governance arrangements in which corporations and industries play a central role. In many issue areas traditional modes of governing through intergovernmental and treaty relations are complemented with soft law, giving rise to new forms of global regulation $[2,15,38]$. Our focus on corruption control also ties in with the growing interest among scholars of management, organization, communication and international business studies in exploring corruption and corruption control mechanisms at the firm or industry levels. This includes a focus on the relationship between corruption control in organizations and the wider corporate social responsibility agenda [4, 37, 40, 44]; between forms of hidden or anonymous organizing [52] and the project of accountability and transparency so characteristic of our times $[19,31$, 32]; and, not least, between corruption and aspirations of moral learning and education at universities and business schools $[54,56]$.

Here we address the interdependencies between public and private regulation in corruption control. Adapting insights from Haufler [26] and Vogel [55] it is useful to think of corruption control in terms of (a) traditional regulation developed, promulgated 
and enforced by governments, either on their own or in cooperation with other governments through international organizations; (b) industry self-regulation and coregulation, where private actors either develop their own standards and codes of conduct independently of governments, or engage in co-regulation with governments that have set up the regulatory goals but leave it to private actors to define the means of goal achievement; and (c) multi-stakeholder regulation or civil regulation, where corporate actors engage with other actors in the development, implementation and enforcement of standards of various kinds.

Traditional, regulatory attempts to control corruption are relatively recent, beginning with the emergence of state laws as well as inter-state conventions that address corruption as subject to regulatory intervention. The lax engagement by governments in corruption control that characterizes most of history up to the final decades of the 20th century is now complemented by multiple international conventions, amendments to national legislations and in many countries also by the development of official anti-corruption agencies. The development took off with the US Foreign Corrupt Practices Act (FCPA) in 1977, accelerated throughout the following decades and particularly during the 1990s and 2000s with various regional and broader international conventions, including the OECD Convention on Combating Bribery of Foreign Public Officials in International Business Transactions, and the United Nations Convention against Corruption, amongst other significant initiatives [53, 59]. That national legislation on the matter is still important has been testified by the recent US Dodd Frank, and not least the UK Bribery Act, which has extra-territorial provisions (Nichols, 2012). These legal initiatives are not the only ones in the area of corruption control yet they make up the key constituents of what some scholars have termed the global prohibition regime against corruption [3, 20, 61].

While pointing to the centrality of these legal developments we also need to emphasize the much wider range of norms, mechanisms and techniques through which corruption control is thought to be achieved, however indirectly these are operating. Formal-legal developments rarely emerge out of the blue but are contingent on social forces and other regulatory dynamics emerging 'beyond the state' [14, 45, 51]. The puzzle described by David Levi-Faur [36, p. VII] in a comment on the changes in the organization of capitalism aptly captures the complexity of contemporary regulatory landscapes: "A regulatory explosion-the proliferation of different mechanisms of control at both the national and global level-is balancing the effects of neoliberal reforms and is creating a new global order that is characterized in important ways by regulation, regulocrats, regulatory agencies and regulatory networks." The emergence of these new modes of regulation are, as Levi-Faur argues, rather puzzling, because "In an era of liberalization, privatization and deregulation, the number, forms and sources of regulation were expected to be on the decline." This observation is important because it points to a characteristic feature of contemporary corruption control: it takes place in the context of increasing state as well as non-state regulation at multiple levels. Perhaps the broader context can be characterized as one of regulatory capitalism [7]. Contrary to the conventional imagery of markets as the anti-thesis of regulation in contemporary societies, what this conceptualization allows us to see is the increasing perception that markets and market actors provide important regulatory mechanisms both within and outside the state. In other words, if processes of privatization and liberalization have formed part of societal changes over the past decades, which they indeed have, they have 
not left markets unregulated nor hollowed out the state, but rather spurred the proliferation of technologies of regulation emanating from both state and non-state actors.

If regulatory capitalism involves more regulation of as well as by the state it also includes civil regulation [55], which refers to the voluntary, non-state industry and cross-industry codes that specify the social responsibilities of global firms in wide range of issue areas. A central feature of civil regulation is that its legitimacy and implementation is not necessarily directly rooted in public authority, but rather in soft law, the violator of which will suffer penalties of the market, including naming and shaming, rather than legal sanctions in the strict sense of the term. Importantly, civil regulation is not about a privatization of business regulation in terms of removing corporations from public scrutiny, but rather about inventing non-state mechanisms for governing corporations, making corporations visible and thereby both the subjects and objects of governance. Another way to put this is that if regulatory capitalism implies the privatization of the public it can also be said to involve the publicization of the private, with public law values like transparency increasingly shaping companies [7, 42, 43]. This also means that private actors come to have a regulatory, political role within the larger social and political architecture [50].

Historically business self-regulation preceded government regulation and mostly concerned regulatory functions such as price, quality controls and technical standards aimed at lowering transaction costs. However, civil regulation relates to the contemporary broadening of public expectations of corporate social responsibility and has emerged as a response to increasing political and social pressures on business [50]. Civil regulation involves monitoring by stakeholders outside the company, which stands in contrast to the traditional business self-regulation typically controlled by firms themselves [55]. Civil regulations provide more flexible norms and procedures throughout regulatory processes than the top-down command-and rule principle embedded in the hard law of traditional regulation. Yet soft law is sometimes nested into formal legal systems, pointing to the coexistence between hard and soft law. Further, hard law can be stated in terms of flexible standards, targets, guidelines or benchmarks, rather than as precise requirements, just as it may mandate specific management practices rather than specific inputs or outputs, or call for disclosure or dialogue. Importantly, in many places state agencies can grant relief from substantive sanctions for companies that accept voluntary obligations and otherwise cooperate in achieving goals set by governmental authorities. Sometimes soft commitments can feed back into hard law [2]. What is important in all cases is the increasing de-facto establishment of private actors in a regulatory role and without a governmental power to enforce rules and to sanction deviant practices in any direct way.

Many of these characteristics can also be found in the current development of corruption control. As we have seen the development of state-driven hard law initiatives continue to play an important role and yardstick for corruption control work, but a fundamental de-centering of norm-making, norm-implementation and norm-enforcement of corruption control is also taking place. In particular we have seen the emergence of initiatives promoted by intergovernmental organizations and hybrid organizational forms and networks operating at local and transnational levels. Corporations, industries and NGOs have become involved in such boundary-crossing anti-corruption work. Examples include the UN Global Compact's Principle 10 against Corruption, the Partnering Against Corruption Initiative (PACI), the Extractive Industries 
Transparency Initiative (EITI), the anti-corruption measures and standards under the novel ISO 26000, not to forget the pioneering initiatives by the world's foremost NGO in anti-corruption, Transparency International. At the level of practical standards and organizational designs for corruption control, such decentering 'beyond the state' is epitomized by the rise of more or less voluntary modes and techniques of value-based reporting and monitoring of business activity and the engagement of private consultancies and new media in such surveillance; new techniques of dialogue and disclosure as soft law characteristics become nested into hard law [28, 29] as well as corporate participation in voluntary disclosure programs like the those developed by the World Bank, which combine failure to disclose with blacklisting and naming-and-shaming [22]; novel teaching and pedagogical approaches to the training of company leaders, employees, university and business school students in anti-corruption, spearheaded by different agencies under the United Nations and including transnational initiatives such as the Principles for Responsible Management Education (PRME) and the AntiCorruption Academic Initiative (ACAI); and, not to forget, the new organizational designs of collective action in the field of anti-corruption, which emphasize mutual trust and cooperation. Examples include organizational arrangements such as Integrity Pacts, an instrument developed by Transparency International for preventing corruption in public contracting, and the Maritime Anti-corruption Network (MACN), which seeks to improve corporate practice in the maritime industry for tackling bribes through collaboration with governments and international organizations in markets where corruption is rife.

\section{The contributions}

Obviously, the question is how far and deep these multiple regulatory processes are going. This special issue brings together six articles that relate closely to the discussions we have sketched out above. They analyze overall changes in regulatory landscapes (Nicholas Lord), the perceptions amongst anti-corruption organizations towards the role of the private sector in corruption control (Grant Walton), the promises and perils of corporate anti-corruption compliance programs (Guillermo Jorge and Fernando Felipe Basch; Julian Klinkhammer); private law approaches in corruption control (Paola Mariani); and moral learning at higher education (Christian Hauser, Franz Kronthaler and Katharina Becker). Each of the articles investigates the construction of corruption control practices drawing on empirical investigation.

Nicholas Lord's article, Regulating transnational corporate bribery: Anti-bribery and corruption in the UK and Germany, focuses on the central mechanisms increasingly deployed in the regulation of transnational corporate bribery: enforcement (e.g. criminal prosecution, civil sanctioning), self-regulatory (e.g. transnational business initiatives, corporate compliance) and hybrid (e.g. self-reporting, self-investigation) mechanisms. In outlining this complex regulatory landscape, Lord demonstrates how it incorporates a diverse array of regulatory actors, including state and non-state operating on varying levels of formality, with self-regulatory measurements differing in terms of their mandatory/voluntary requirements and manufactured/organic formation. With reference to recent developments in the UK and Germany, where largescale cases involving MNCs like BAE Systems and Siemens illustrate the difficulties 
faced by the two states in controlling complex transnational and multijurisdictional crimes, he shows how these mechanisms are emerging as part of the responses to controlling transnational corporate bribery. The specific regulatory systems differ in the two countries, but they are both key players in the global political economy and categorized by the OECD as 'active enforcers' of the OECD Convention. However, the emergence of a variety of enforcement, self-regulatory and innovative hybrid mechanisms may erroneously leave the impression that the new regulatory landscape is sufficient in the fight against transnational corporate bribery. But this is not the case. Most corporate bribery is still likely to go undetected, outweighing the capacity of regulatory mechanisms in the two countries. This situation may lead to what Lord terms the "default position of accommodation" by state agencies. This position is not only a result of the practical and resource limitations of the regulatory mechanisms, but also, even where the will to enforce the law and pressure from civil society are high, a consequence of the strength of political and economic ideologies favoring corporate power.

In the next article, The limitations of neoliberal logic in the anti-corruption industry: lessons from Papua New Guinea, Grant Walton shares many of these critical concerns regarding the efficacy of corruption control. However, Walton's analytical lens is different from Lord's in that he analyzes the anti-corruption industry's approaches towards the role of the private sector in corruption and corruption control. Key international organizations have indeed come to support anti-corruption initiatives and these reflect an increasing awareness of businesses' key role in corruption. However, it is also clear that the initiatives are dominated by a particular approach to corruption control which, backed by mainstream bodies of economic theory, claims that deregulation, liberalization and privatization is crucial in order to reduce rent-seeking. Anti-corruption seems connected to broader projects of neoliberal market-oriented reforms, something which has triggered criticism by scholars who argue that neoliberal reforms have not reduced the role of the private sector it corruption, but rather expanded it. Walton analyzes the specific case of Papua New Guinea (PNG) where corruption has been rife, particularly in the forestry and mining sectors. By examining how two international anticorruption organizations, AusAID and the PNG chapter of Transparency International have perceived and worked with the private sector in the country, he finds that there have been some initiatives designed to address, and raise awareness about private sector corruption in the country, reflecting international trends. At the same time, however, the private sector has been viewed, often uncritically, as an anti-corruption champion by the organizations. More generally, Walton argues that despite more emphasis in the international discourse about the private sector's responsibility if not complicity in corruption, in countries like PNG, a neoliberal logic about the nature of the state still guides much anti-corruption activity. His findings suggest that simply focusing more on corruption in the private sector, making declarations about the newness of this focus and ratifying it in conventions, however laudable, does not change much as long governments and associated regulations are mainly seen as rent-seeking institutions.

Whereas Walton addresses the problem of the role of business in corruption and corruption control by focusing on the political rationales of international organizations and by critically discussing the implications of particular bodies of academic literature shaping the mainstream anti-corruption industry, Guillermo Jorge and Fernando Felipe Basch investigate more directly the development of anti-corruption compliance 
programs in corporations. Asking the question How has the private sector reacted to the international standard against transnational bribery? the two authors examine the particular case of Argentina. They note that most multinational corporations today do have anti-corruption programs, reflecting that the risk of bribing foreign public officials has increased for companies based in OECD countries and those listing in their stock markets. There are also signs that corporations seek to extend anti-corruption compliance programs to subsidiaries and other actors in their value chain, something which-if successful-may have a preventive and thus transformative potential well beyond the individual company. The empirical study consists of in depth interviews and a survey conducted among companies based in Argentina. Even if things have developed over the past years anti-corruption compliance in Argentina is placed closer to "paper" and "cheap-talk" type of compliance programs rather than truly committed compliance practices. Nonetheless, the developments in Argentina also suggest an incipient change in companies produced by international standards against bribery, changes that are linked wider global trends in anti-corruption. The authors trace the origin of corporate compliance programs to American Law, and they analyze the development of compliance programs since the 1970s in the context of various national and international legal initiatives. While none of these initiatives set compliance programs as mandatory, there seems to be a convergence internationally around a model of corporate liability that attributes corporate responsibility for failure in preventing bribery, which raises new questions as to how far organizational cultures can be changed in the direction of preventing corruption.

According to Julian Klinkhammer, author of On the dark side of the code: organizational challenges to an effective anti-corruption strategy, corporations have been fighting for decades to eliminate corruption. However, despite the proliferation of compliance programs and a recurrent surge of interest in business ethics, commercial bribery still prevails as a strategy for economic success. In his empirical in-depth study of the case of corruption in Siemens AG, Klinkhammer demonstrates that the people who sustained corruption in the company were neither especially greedy nor immoral persons. Rather, they were entangled in the practice of bribery as this was an integral aspect of Siemens' business dealings in different divisions. Here, bribery was considered useful in relation to commercial activity and legitimized by the company's organizational culture. In fact, neither consistent anti-corruption norms nor severe formal sanctions were able to deter certain employees from deviant behavior. Klinkhammer points out how organizational culture can provide an explanation for the paradox of formally having compliance programs in place while continuing the practice of bribery. In seeking to bridge the gap between what he regards as criminological research on corruption and organizational theory he compares three diverging assumptions about corruption in organizations: (1) private gain (2) cognitive normalization, and (3) organizational cultures. He concludes that the structural causes of corrupt practices fit the definition of 'useful illegality', as originally formulated by Niklas Luhmann. This sociological concept resembles the criminological idea of corporate crime. Importantly however, it also emphasizes the cultural factors that undermine management's preventive strategies.

In the next article, How damages recovery actions can improve the fight against corruption: the crisis of criminal law policies and the role of private enforcement in an Italian case of judicial corruption, Paola Mariani investigates another front that has 
developed recently in the fight against corruption in addition to the surge of corporate compliance programs and other self-regulatory measures referred to in the articles by Lord, Jorge and Bosch, and Klinkhammer: the private law approach, which is a complement to criminal law policies. In principle, it may constitute a disincentive against corrupt practices in that the protagonist of a corrupt practice may be subject not only to criminal proceedings by public authority but also to civil proceedings by the victims of the corrupt practice. Mariani draws a parallel to competition law in the European Union and points out that the idea of using private law instruments in order to achieve a public policy goal is not new. However, it relies on the possibility of creating a social and legal environment that does not deter but rather encourages the victims of a criminal practice to promote damages action. The question is whether this principle can also be transposed to the fight against corruption. Formally, both the UN Convention against Corruption and the Council of Europe Civil Law Convention open up for effective remedies for persons suffering damages from corruption. Analyzing the Italian context and one of the first cases involving damages actions resulting from corrupt practices, Mariani considers in detail two of the main obstacles to civil actions in this field: evidence and the quantification of damages. She shows that the case bears some promises for future anti-corruption work as it demonstrates how the use of evidence collected in criminal investigations for corruption trials, which are highly fact intensive, helps to overcome the burden of proof faced by the victim. On the other hand, however, there is a serious problem when it comes to the quantification of damages caused by the corrupt practice and suffered by the victim.

Finally, in Fostering management education to deter corruption: What do students know about corruption and its legal consequences? Katharina Becker, Christian Hauser and Franz Kronthaler take us in to the world of higher education to analyze how key knowledge institutions in contemporary societies prepare future generations of specialists and professionals for corruption control. Like in the other articles of this special issue the focus is on institutional developments that may provide new ways of dealing with the problem of corruption and the educational field is an often overlooked area in these discussions. In fact education is, as a vast body of social research has shown one of the central nodes for reproduction and change of the social order. What and how we teach our students about corruption and corruption control will have regulatory implications. The article builds on the assumption that as future experts, executives or entrepreneurs students at universities and business schools are of key importance in the combat of corruption and bribery. Specifically, it analyzes the current level of knowledge about corruption and its legal consequences among university students. Based on the collection and analysis of survey data from undergraduate and graduate students from all academic disciplines at four major universities in Switzerland the study shows that the majority of students have difficulty identifying corrupt behavior and its legal consequences. Law students achieve slightly better results. However, even law students demonstrate a significant lack of knowledge of corruption issues. In particular, most of the students are unaware that corruption that occurs abroad can also be prosecuted in Switzerland. Based on these results, it is the authors' suggestion that the limited knowledge among students regarding corruption and its legal consequences should be confronted by better integrating the teaching and study of anti-corruption-related into the curricula of universities and business schools. 
We began this essay by noting how the anti-corruption consensus is both contingent upon and itself producing a wide variety of regulatory processes, which not only to some degree blurs established distinctions between the public and private, the national and international, but also involves a host of new actors, commercial and non-commercial. From the discussions in the six articles the question arises whether there are any real alternatives to the many varieties of corruption control in transnational governance. We hope that this special issue lays a foundation for thinking more deeply about the regulatory complexity in corruption control, about its potential alternatives as well as for further investigating the processes behind the increasing focus on corruption control, including the role of the private sector and soft law.

\section{References}

1. Abbott, K., \& Snidal, D. (2002). Values and interest: international legalization in the fight against corruption. The Journal of Legal Studies, XXXI, 141-178.

2. Abbott, K., \& Snidal, D. (2009). Strengthening international regulation through transnational new governance: overcoming the orchestration deficit. Vanderbilt Journal of Transnational Law, 42, 501578.

3. Andreas, P., \& Nadelmann, E. (2006). Policing the globe. Criminalization and crime control in international relations. New York: Oxford University Press.

4. Ashforth, B. E., Goia, D. A., Robinson, S. L., \& Trevino, L. K. (2008). Re-viewing organizational corruption. Academy of Management Review, 33(3), 670-683.

5. Blundo, G., \& De Sardan, J. P. O. (2006). Everyday corruption and the state: Citizens and public opinion in Africa. London: Zed Books.

6. Bracking, S. (Ed.). (2007). Corruption and development. The anti-corruption campaigns. Houndsmills: Palgrave.

7. Braithwaite, J. (2008). Regulatory capitalism: How it works, ideas for making it work better. Cheltenham: Edward Elgar.

8. Brown, E. D., \& Cloke, J. M. P. (2011). Critical perspectives on corruption: an overview. Critical Perspectives on International Business, 7(2), 116-124.

9. Bukovansky, M. (2006). The hollowness of anti-corruption discourse. Review of International Political Economy, 13(2), 181-209.

10. Calderón, R., Álvarez-Arce, J. L., \& Mayoral, S. (2008). Corporation as a crucial ally against corruption. Journal of Business Ethics, 87(1), 319-332.

11. Campos, J. E., \& Pradhan, S. (Eds.). (2007). The many faces of corruption. Tracking vulnerabilities at the sector level. Washington: The World Bank.

12. Cutler, A. C., Haufler, V., \& Porter, T. (Eds.). (1999). Private authority and international affairs. Albany: State University of New York Press.

13. De Sousa, L., Larmour, P., \& Hindess, B. (2009). Governments, NGOs and anti-corruption. The new integrity warriers. London: Routledge/ECPR Studies.

14. Dean, M. (1999). Governmentality: Power and rule in modern society. London: Sage.

15. Djelic, M.-L., \& Sahlin-Andersson, K. (2006). Transnational governance: Institutional dynamics of regulation. Cambridge: Cambridge University Press.

16. Everett, J., Neu, D., \& Rahaman, A. S. (2007). Accounting and the global fight against corruption. Accounting, Organizations and Society, 32, 513-542.

17. Fuchs, D. (2005). Commanding heights? the strength and fragility of business power in global politics. Millennium-Journal of International Studies, 2005(33), 771-801.

18. Galang, M. N. G. (2012). Victim or victimizer: firm responses to government corruption. Journal of Management Studies, 49(2), 429-462.

19. Garsten, C., \& de Montoya, M. L. (2008). Transparency in a new global order: Unveiling organizational visions. Cheltenham, UK: Edward Elgar.

20. Getz, K. A. (2006). The effectiveness of global prohibition regimes. Corruption and the anti-bribery convention. Business \& Society, 45(3), 254-281. 
21. Graf, J.-C., \& Nölke, A. (2007). Transnational private governance and its limits. London: Routledge.

22. Hansen, H. K. (2012). The power of performance indices in the global politics of anti-corruption. Journal of International Relations and Development, 15(4), 506-531.

23. Hansen, H. K. (2011). Managing corruption risk. Review of International Political Economy, 18(2), 251-275.

24. Hansen, H. K., \& Salskov-Iversen, D. (2008). Critical perspectives on private authority in global politics. Basingstoke: Palgrave Macmillan.

25. Hall, R. B., \& Biersteker, T. (Eds.). (2002). The emergence of private authority in global governance. Cambridge: Cambridge University Press.

26. Haufler, V. (2006). Global governance in the private sector. In C. May (Ed.), Global corporate power. Boulder: Lynne Rienner Publishers.

27. Herzig, C., \& Moon, J. (2013). Discourses on corporate social ir/responsibility in the financial sector. Journal of Business Research, 66(10), 1870-1880.

28. Hess, D. (2009). Catalizing corporate commitment to combat corruption. Journal of Business Ethics, $88,781-790$.

29. Hess, D., \& Ford, C. L. (2008). Corporate corruption and reform undertakings: a new approach to an old problem. Cornell International Journal of Law, 41(2), 307-346.

30. Hindess, B. (2005). Investigating international anti-corruption. Third World Quarterly, 26(8), 13891398.

31. Holzner, B., \& Holzner, L. (2006). Transparency in global change. The vanguard of the open society. Pittsburgh: University of Pittsburgh Press.

32. Hood, C., \& Heald, D. (Eds.). (2006). Transparency: The key to better governance? London: OUP/ British Academy Proceedings of the British Academy.

33. Johnston, M. (2005). Syndromes of corruption. Wealth, power, and democracy. Cambridge: Cambridge University Press.

34. Krastev, I. (2000). The strange (re)discovery of corruption. In L. Dahrendorf et al. (Eds.), The paradoxes of unintended consequences. Budapest: CEU Press.

35. Larmour, P. (2006). Civilizing techniques: Transparency international and the spread of anti-corruption. In B. Bowden \& L. Seabrooke (Eds.), Global standards of market civilization. London: Routledge.

36. Levi-Faur, D. (2008). Foreword. In J. Braithwaite (Ed.), Regulatory capitalism: How it works, ideas for making it work better (pp. vii-x). Cheltenham: Edward Elgar.

37. Luo, Y. (2006). Political behavior, social responsibility, and perceived corruption: a structuration perspective. Journal of International Business, 37, 747-766.

38. Mattli, W., \& Woods, N. (2009). The politics of global regulation. Princeton: Princeton University Press.

39. May, C. (2006). Global corporate power. Boulder: Lynne Rienner Publishers.

40. Misangyi, V. F., Weaver, G. R., \& Elms, H. (2008). Ending corruption: the interplay among institutional logics, resources, and institutional entrepreneurs. Academy of Management Review, 33(3), 750770 .

41. Nichols, P. M. (2012). The business case for complying with bribery laws. American Business Law Journal, 49(2), 325-368.

42. O'Callaghan, T. (2007). Disciplining multinational enterprises: the regulatory power of reputation risk. Global Society, 21(1), 95-117.

43. Power, M. (2007). Organized uncertainty. Designing a world of risk management. Oxford: Oxford University Press.

44. Rodríquez, P., Siegel, D. S., Hillman, A., \& Eden, L. (2006). Three lenses on the multinational enterprise: politics, corruption, and corporate social responsibility. Journal of International Business Studies, 37, 733-746.

45. Rose, N., \& Miller, P. (1992). Political power beyond the state: problematics of government. The British Journal of Sociology, 43(2), 173-205.

46. Rose-Ackerman, S. (1999). Corruption and government: Causes, consequences and reform. Cambridge: Cambridge University Press.

47. Rose-Ackerman, S. (2002). Corruption and the global corporation: Ethical obligations and workable strategies. In M. Likovsky (Ed.), Transnational legal processes. Globalisation and power disparities. Trowbridge: Cromwell Press.

48. Ruggie, J. G. (2005). Reconstituting the global public domain-issues, actors, and practices. European Journal of International Relations, 10(4), 499-531.

49. Sampson, S. (2010). The anti-corruption industry: from movement to institution. Global Crime, 11(2), 261-278. 
50. Scherer, A. G., \& Palazzo, G. (2011). The new political role of business in a globalized world: a review of a new perspective on CSR and its implications for the firm, governance, and democracy. Journal of Management Studies, 48(4), 899-931.

51. Scott, C. (2004). Regulation in the age of governance: The rise of the post-regulatory state. In J. Jordana \& D. Levi-Faur (Eds.), The politics of regulation. Institutions and regulatory reforms for the age of governance. Cheltenham: Edward Elgar.

52. Scott, C. R. (2013). Anonymous agencies, backstreet businesses and covert collectives: Rethinking organizations in the 21st century. Stanford: Stanford University Press.

53. Spahn, E. (2012). Multi-jurisdictional bribery law enforcement: The OECD anti-bribery convention. Virginia Journal of International Law 1 (2012); New England Law | Boston Research Paper No. 13-04. Available at SSRN: http://ssrn.com/abstract=2023138.

54. Vaara, E., \& Faÿ, E. (2012). Reproduction and change on the global scale: a Bourdieusian perspective on management education. Journal of Management Studies, 29(6), 1023-1051.

55. Vogel, D. (2010). The private regulation of global corporate conduct. Business \& Society, 49(1), 68-87.

56. Wankel, C., \& Stachiwitz-Stanusch, A. (2011). Management education for integrity; transcending amoral business curricula. In C. Wankel \& A. Stachowitz-Stanusch (Eds.), Management education for integrity: Ethically educating tomorrow's business leaders. Bingley: Emerald Group.

57. Warner, C. M. (2007). The best system money can buy. Corruption in the European Union. New York: Cornell University Press.

58. Weaver, C. (2008). Hypocrisy trap. The world bank and the poverty of reform. Princeton: Princeton University Press.

59. Webb, P. (2005). The United Nations convention against corruption. Global achievement or missed opportunity. Journal of International Law, 8(1), 191-229.

60. Williams, P. (2002). Transnational organized crime and the state. In R. B. Hall \& T. J. Biersteker (Eds.), The emergence of private authority in global governance (pp. 161-182). Cambridge: Cambridge University Press.

61. Wrage, S., \& Wrage, A. (2005). Multinational enterprises as "moral entrepreneurs" in a global prohibition regime against corruption. International Studies Perspectives, 6, 316-324. 